\title{
Ecological Studies on the Biological Production of Young Amberfish Community in the Sendai Bay-III Movement of the Young Amberfish
}

\author{
Akihiro OKATA* \\ (Received May 11, 1976)
}

\begin{abstract}
Mark and recapture experiments on young amberfish were conducted in the Sendai Bay and at a coast along Joban to know their movements, sojourning time, growth and population size. During the period from 1968 to $1972,1,387$ individuals of the fish were released and 79 of them were recaptured.

Schools of young amberfish in the 0-age group migrate toward the coast of Sendai Bay, leaving drifting-sea-weeds, during the periods June-July when the Kuroshio water mass approaches along the coasts of the Tohoku Region. Judging collectively from the relationships between the positions of release and recovery they appear to be sojourning in the Bay or neighbouring areas till late September, and then move toward the south as the water temperature falls. By the following spring, about May, fish in the 1-year age group migrate gradually up north by way of Joban coast. Some schools of fish among the population in the 0-age group presumably stay over the coldest season in the neighbourhood areas of Boso peninsula.
\end{abstract}

In the previous papers ${ }^{1-2)}$, the author showed a production structure of the community including the young amberfish, Seriola quinqueradiata, and dealt with the relationships between fish community and fauna. Production structure is thought to be a cross section of a dynamic process in the system of community which contains the kinetics of various species populations. This implies that the structure has been constructed by a resultant force consisting of both biotic and abiotic components in the ocean ecosystem.

In the case dealing with the biological production in marine reputed to be an open system, great care must be taken to accept some methods used in a field of closed system such as lakes and marshes. Especially, concerning to the production process of migratory fishes in the ocean, it is necessary to pay special regard to the time-space fluctuation of movement of fish school and composition of a community, backed by species specific lives adapted to survive in marine environments.

When we approach to problems of production process in a biotic community, it, first of all, is a desirable way to start from the production of terminal species positioning at high food niche, and we may easily go on study to various species in lower food niche one after another following to food chains.

In order to make clear the production process of young amberfish and to find a proper

* Fisheries Experimental Station of Ibaraki-Ken, Nakaminato, Japan (茨城累水試敦埸) 
method for time-space limitation of the population migrated in the coastal area, release and recapture experiment had been conducted in the Sendai Bay and at far coast of Joban during the period from 1968 to $1972^{3-6)}$.

Up to this day, with respect to the migration of amberfish, several investigations have been tried over the past years, and from the results we can graspe an approximate state of migration along the Pacific coast of Japan ${ }^{7}$. In recent years, details on the migration have considerably clarified by means of a large-scale experiment, conducted during the period from 1963 to $1965^{8}$. To sum up the results of these investigations, within the limitation of the Pacific coast subpopulation of amberfish, it is clearly recognized that there is a difference in the patterns of migration between the large sized fish and the small sized fish. The large sized fish migrate southward in the Tohoku and Tokai-Nankai Regions in the winter-spring season and migrate northward in the summer-autumn season. On the other hand, the small sized young fish show north-south migration within the Tohoku Region but present no evidence of movements with the Tokai-Nankai Region or between these two Regions ${ }^{9}$

The present paper deals mainly with the movement of the fish school, presumed by the relation between release and recapture positions, basing on the result of the experiment and on records of catch by set-nets in several fishing grounds along the coast from Joban to the north part of Miyagi Prefecture.

\section{Material and Method}

In order to make an estimation for sojourning time, distribution, migration, growth and population size of young amberfish migrated in the Sendai Bay, 1,387 individuals of the fish were released by means of tagging method, during 5 years from 1968 to 1972 , in the Bay and at a coast off Joban.

The amberfish used in the experiment were mainly obtained by the set-nets, and the range of fork length were from 20 to $35 \mathrm{~cm}$. To acquire the growth rate of the fish, body length and weight were measured just before the releasing experiment. In measuring fish body weight with a beam on board a boat, her rock makes it difficult to read notches accurately, and in the case of tagging operation it may well be that food in the stomach will give an error to the value of body weight and will increase the mortality by anesthesia. Accordingly, before tagging operations, captured fish had been reared in a crawl on the open sea for 1 or 2 days abstaining from food, and measured for weight and length on the shore. At the time of operation, they were put under anesthesia with $0.5 \%$ sea water solution of urethan, and were pieced with dart type tags on their dorsal portion, as shown in Figure 1. Then, tagged fish were transported by ship to releasing station, supplying oxygene into the rearing tanks. Concerning to problems on tagging technique and the 
type of tag, as previously stated in the interim reports for J.IBP.PM. ${ }^{3-6)}$, the dart type has a gratifying result as compared with the other types of tag such as anchor and Atkins. Accordingly, most of tags used in the experiment were dart type, made of the ruddy plastic tube with a diameter of $1.6 \mathrm{~mm}$ and a length of $47 \mathrm{~mm}$, set up with a

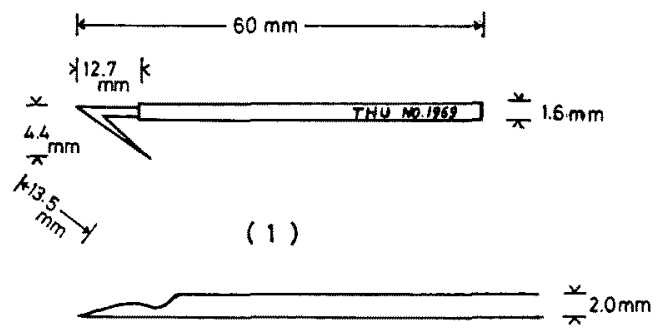

(2)
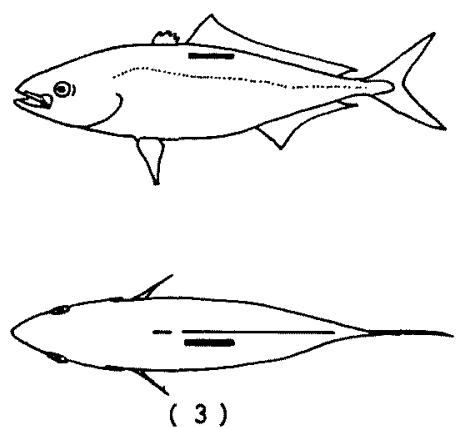

Fig. 1. Diagram showing the type of tag and the attachment site.
(1); tag
(2); needle
(3); attachment site perimental stations.

\section{Results}

Releasing experiments had been carried out 16 times repeatedly at 22 stations, and 1,387 individuals of the amberfish were released and 79 of them recaptured, as shown in Table 1. The recapture rates of experiments dispersed from 0 to $20.8 \%$, and the average was $5.7 \%$.

In the first place, taking aim at the high zenith of fishing, during from 1968 to 1970 , 504 individuals had released and 24 recaptured, as shown in Table 2. The relationships between release and recapture positions are shown in Figure 2. Each position of release and recapture is only connected by arbitrary line, which does not necessarily express the actual pass way of the tagged fish. Numbers in parentheses indicate the period of free living days of the recapture fish after liberation. Marked fish had been recovered by the set-nets along coast of the Bay, within the period of 30 days after releasing for the most part. A record of the longest period of free living was 90 days. Concerning about 
Table 1. Results of releasing and recovering of young amberfish in Sendai Bay and the coast of Joban during the period 1968-1972

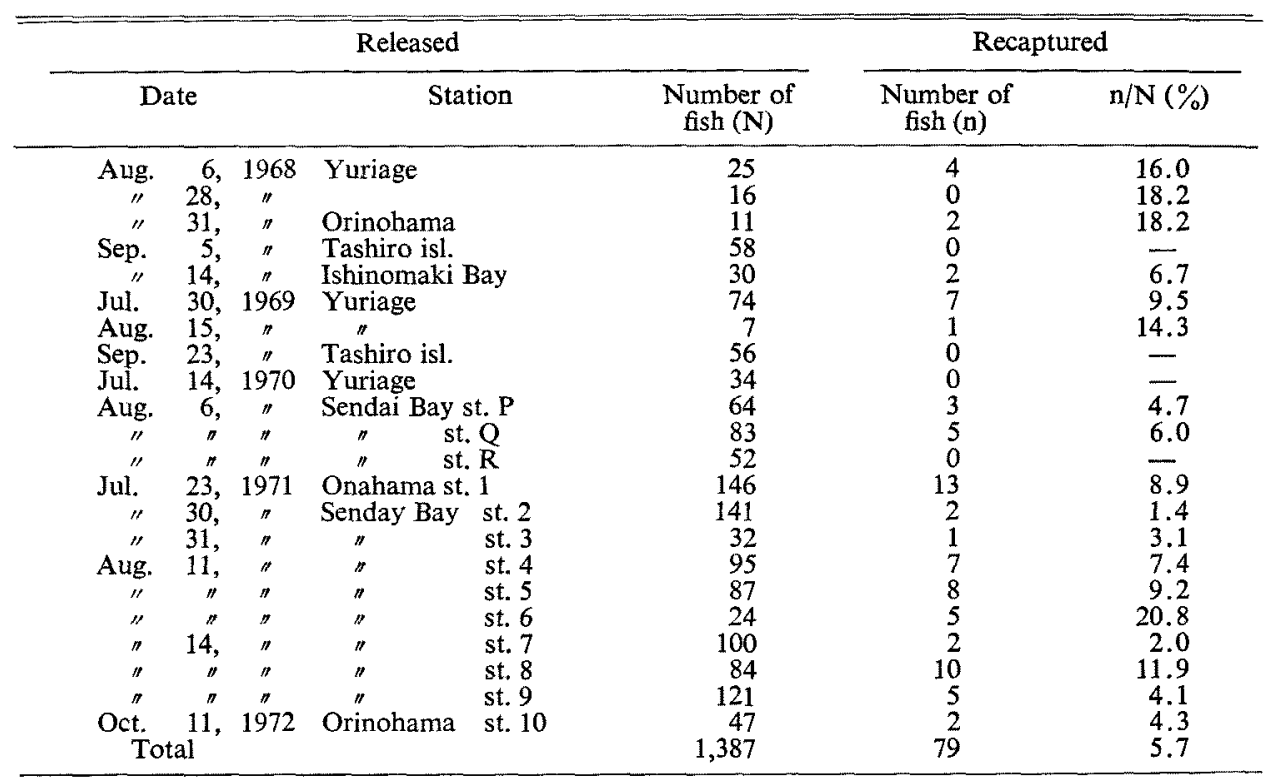

Table 2. Results of releasing and recovering experiments with young amberfish in the Sendai Bay during the period 1968-1970. Body weights shown in parenthesis are estimated value calculated from the relation of body weight to fork length. $\mathrm{L}_{1}$ and $\mathrm{W}_{2}$ are respectively the initial body length and weight at release, and $\mathrm{L}_{2}$ and $\mathrm{W}_{2}$ are those at recaptured

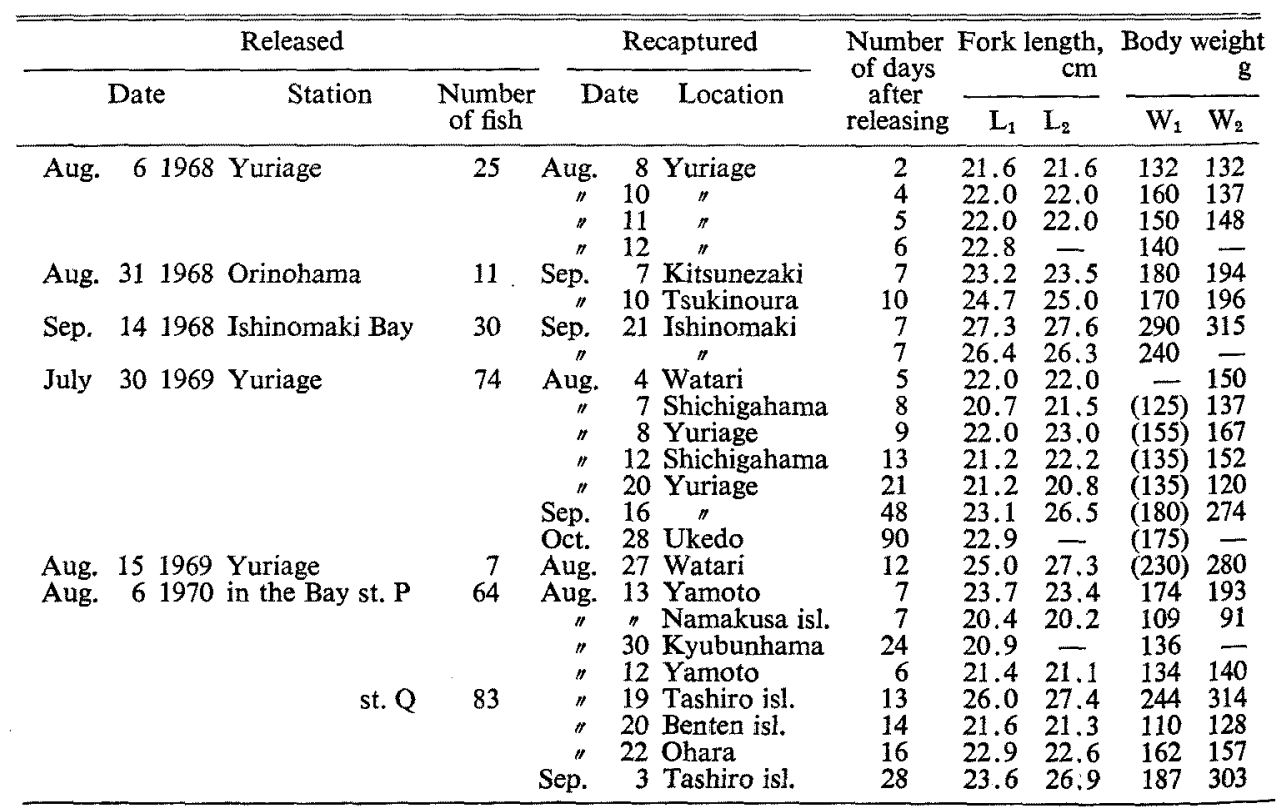


relationships between release and recapture positions, it was found that the fish released in the south-west part of the Bay had been recaptured mainly in the south area of mouth part of Matsushima bay, and that groups of the fish, released in the inner part and the north-east part, both had been recaptured in much about the same area as each releasing location.

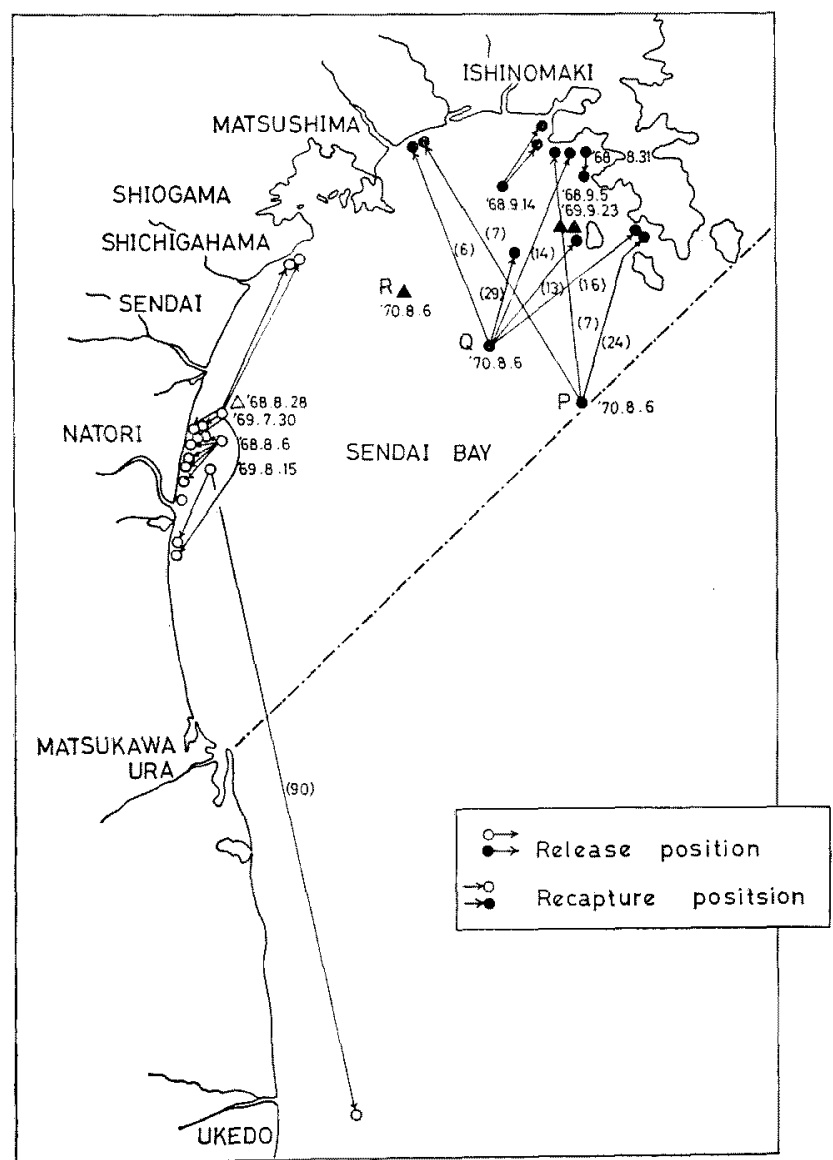

Fig. 2. Movement of marked amberfish released in the Sendai Bay, during the period from 1968 to 1970 . Each position of release and recapture is only connected by an arbitrary line, and arrows show the direction of movement of the fish. Circle: group of the fish released at the south area of the Bay. Black circle: group of the fish released at the north part of the Bay. Triangle: group of the fish having never been recaptured.

The next, the result of experiment, carried out in the Sendai Bay and at a coast off Joban during the period from 1971 to 1972, are shown in Tables 3, 4 and Figure 3. Among the fish released off Onahama in Fukushima Prefecture, most of recovery concentrate upon some restricted coast area from the south part of Fukushima Prefecture to the north part 
of Ibaraki Prefecture, within a period during from 7 to 30 days after releasing, with the exception of two instances, that the one recaptured in the Sendai Bay after 75 days and the other in the area of Kashimanada after 102 days.

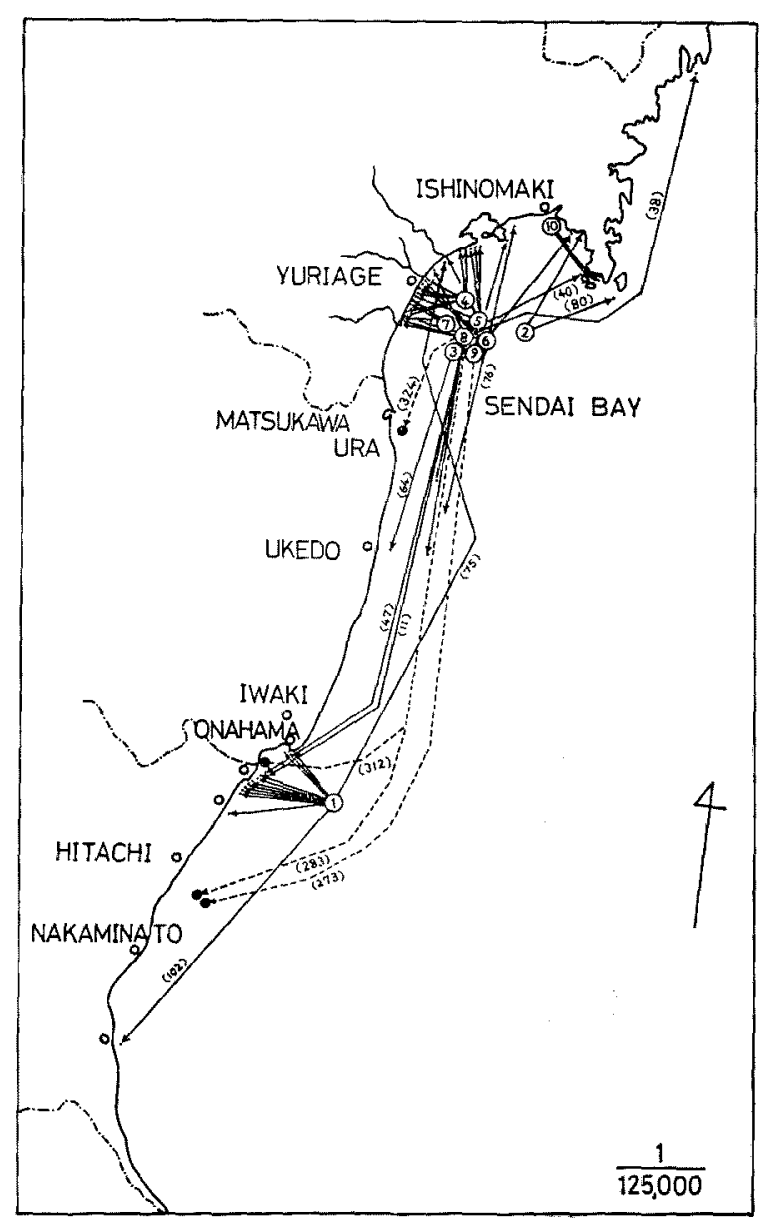

Fig. 3. Movement of young amberfish released at nine stations in the Sendai Bay and a station off the coast of Onahama, during the period from 1971 to 1972 . Numbers enclosed with circle represent release stations. A dot shows point the fish recaptured within the same year, and black circle shows place recaptured in the next year. Each position of release and recapture is only connected by an arbitrary line. Number in parenthesis shows days after releasing.

Referring to the experiment, carried out in the Sendai Bay, during the period from July 30 to August 14 in 1971, most of recovery showed remarkable concentration toward the south-west area of the Bay in a short period of time after release. And afterward, the recovery had conspicuously a partiality to the outside of the Bay as times went on. 
Table 3. Results of releasing and recovering experiments with young amberfish in the coast of Joban in 1971

\begin{tabular}{|c|c|c|c|c|c|c|c|c|c|}
\hline \multicolumn{2}{|c|}{ Released } & \multirow{3}{*}{$\begin{array}{c}\text { Number } \\
\text { of } \\
\text { fish }\end{array}$} & \multicolumn{2}{|r|}{ Recaptured } & \multirow{3}{*}{$\begin{array}{l}\text { Number } \\
\text { of days } \\
\text { after } \\
\text { releasing }\end{array}$} & \multirow{2}{*}{\multicolumn{2}{|c|}{$\begin{array}{c}\text { Fork length, } \\
\mathrm{cm}\end{array}$}} & \multirow{2}{*}{\multicolumn{2}{|c|}{$\begin{array}{l}\text { Body weight } \\
\qquad \mathrm{g}\end{array}$}} \\
\hline \multirow{2}{*}{ Date } & \multirow{2}{*}{ Station } & & \multirow{2}{*}{ Date } & \multirow{2}{*}{ Location } & & & & & \\
\hline & & & & & & $\mathrm{L}_{1}$ & $\mathrm{~L}_{2}$ & $W_{1}$ & $\mathrm{~W}_{2}$ \\
\hline \multirow{11}{*}{ July 231971} & 6 miles east of & 133 & Aug. 3 & Hirakata & 11 & 19.5 & 21.0 & 90 & 135 \\
\hline & Onahama st. 1 & & Aug. 6 & $6 n$ & 14 & 19.0 & 20.5 & 88 & 123 \\
\hline & & & $p$ & 7 Onahama & 15 & 22.1 & 23.5 & 105 & 154 \\
\hline & & & $n$ & 8 Hirakata & 16 & 21.3 & 22.4 & 127 & 196 \\
\hline & & & $n \quad 8$ & $8 \quad " \prime$ & 16 & 18.7 & 19.5 & 81 & 104 \\
\hline & & & $\Rightarrow \quad 11$ & 1 Onahama & 19 & 19.5 & 22.5 & 89 & 143 \\
\hline & & & " 12 & 2 Hirakata & 20 & 19.5 & 21.5 & 89 & 164 \\
\hline & & & $\Rightarrow 16$ & $6 "$ & 24 & 18.8 & 20.6 & 78 & 122 \\
\hline & & & " 22 & $n$ & 30 & 22.5 & 26.7 & 148 & 326 \\
\hline & & & Oct. 6 & $\begin{array}{r}\text { Yoshidahama } \\
\text { (Sendai Bay) }\end{array}$ & 75 & 20.1 & 26.9 & 100 & 275 \\
\hline & & & Nov. 2 & Kashima & 102 & 19.9 & 32.6 & 99 & 451 \\
\hline
\end{tabular}

Some moved southward as far as the north coast of Ibaraki Prefecture in a mere 11 days after release, however, others had been recaptured at coasts of Ibaraki Prefecture 273 and 283 days after, and at Fukushima Prefecture 312 and 324 days after releasing. Figure 4 shows relationships between the period of time after release and the recovery station. Relative locations on a north-south line, referring to release and recapture positions, are shown on a transversal axis. Not later than 25 days after release, about $80 \%$ of recaptured fish were occupied by the south-west fishing ground (areas A, B and C), and $20 \%$ by the inner part of the Bay (area D). Informations of the recovery cease for a while, through late in August into September, and resume around from late in September, since when the recovery disperse over a wide area such as the north-east part of the Bay, northward of Oshika peninsula and the coast of Fukushima Prefecture. Thereafter, through late in September into mid-October, the number of recoveries in the south-west part of the Bay increase for the second time, while, the recovery come to the fore in the area of Joban coast. Looking over the state of recoveries of next year after release, it may be recognized that the recovery station of the fish in 1 age of year go up north gradually in accordance with the lapse of time.

Figure 5 shows the feeding rate of tagged fish rearing in outdoor tanks, during the period of descending in water temperature. Their feeding behavior showed liveliness, in the same manner as non-tagged individuals, and falling of tag did not occur at all. Mean feeding rate of 23 individual fish within $30 \mathrm{~min}$ after $24 \mathrm{hr}$ of food deprivation showed about $10 \%$, however, the rate markedly showed a descending tendency under $15^{\circ} \mathrm{C}$. In the case under $10^{\circ} \mathrm{C}$, the rate fell radically in accompaniment with water temperature decline, and showed the values of $4.5-8.0 \%$, and then the rate decreased to the extent of $2 \%$ at $7.5^{\circ} \mathrm{C}$. Furthermore, when the water temperature declined under $7^{\circ} \mathrm{C}$, the fish 
Table 4. Results of release and recapture experiments with young amberfish in the Sendai Bay during the period 1971-1972. $L_{1}$ and $W_{1}$ are respectively the initial body length and weight at release, and $\mathrm{L}_{2}$ and $\mathrm{W}_{2}$ are those at recaptured

\begin{tabular}{|c|c|c|c|c|c|c|c|c|c|}
\hline \multicolumn{3}{|c|}{ Released } & \multicolumn{2}{|r|}{ Recaptured } & \multirow{3}{*}{$\begin{array}{l}\text { Number } \\
\text { of days } \\
\text { after } \\
\text { releasing }\end{array}$} & \multirow{2}{*}{\multicolumn{2}{|c|}{$\begin{array}{c}\text { Fork length } \\
\mathrm{cm}\end{array}$}} & \multirow{2}{*}{\multicolumn{2}{|c|}{$\begin{array}{c}\text { Body weight } \\
\mathrm{g}\end{array}$}} \\
\hline \multirow[t]{2}{*}{ Date } & \multirow{2}{*}{ Station } & \multirow{2}{*}{$\begin{array}{c}\text { Number } \\
\text { of fish }\end{array}$} & \multirow{2}{*}{ Date } & \multirow{2}{*}{ Location } & & & & & \\
\hline & & & & & & $\mathrm{L}_{1}$ & $\mathrm{~L}_{2}$ & $\mathrm{~W}_{1}$ & $\mathrm{~W}_{2}$ \\
\hline Jul. 30 & \multirow{2}{*}{$\begin{array}{l}\text { Center of } \\
1 \text { the Bay St.2 }\end{array}$} & \multirow[t]{2}{*}{141} & Aug. & 20 Orinodama & 21 & 22.6 & 22.2 & 一 & 121 \\
\hline 1971 & & & Oct. & 18 Kinkasan & 80 & 25.7 & 34.9 & - & 616 \\
\hline Jul. 31 & Yuriage St.3 & 32 & Oct. & 3 Haranomachi & 64 & 22.8 & 30.6 & - & 370 \\
\hline \multirow[t]{19}{*}{ Aug. 11} & \multirow{2}{*}{$\begin{array}{l}\text { St. } 4 \\
\left(38^{\circ} 10^{\prime} \mathrm{N}\right.\end{array}$} & \multirow[t]{7}{*}{95} & Aug. & 15 Fukanuma & 4 & 22.2 & 22.6 & 159 & 170 \\
\hline & & & $"$ & 16 Minatohama & 5 & 22.6 & 22.9 & 149 & 166 \\
\hline & \multirow[t]{5}{*}{$\left.141^{\circ} 08^{\prime} \mathrm{E}\right)$} & & & " Yuriage & 5 & 20.4 & 20.4 & 110 & 112 \\
\hline & & & $" \prime$ & $17 \|$ & 6 & 21.8 & - & 124 & - \\
\hline & & & $" 7$ & 22 Matsugahama & 11 & 21.9 & 23.1 & 130 & 174 \\
\hline & & & $n$ & 23 Yuriage & 12 & 24.3 & 25.2 & 180 & 232 \\
\hline & & & $"$ & $" \quad "$ & 12 & 23.2 & 23.7 & 148 & 181 \\
\hline & st. 5 & 87 & Aug. & 13 Yuriage & 2 & 21.5 & - & 125 & - \\
\hline & $\left(38^{\circ} 07^{\prime} \mathrm{N}\right.$ & & $"$ & 14 Minatohama & 3 & 19.9 & 19.9 & 95 & 90 \\
\hline & \multirow[t]{5}{*}{$\left.141^{\circ} 11^{\prime} \mathrm{E}\right)$} & & $"$ & $16 "$ & 5 & 19.6 & 19.7 & 99 & 105 \\
\hline & & & & 22 Fukanuma & 11 & 19.9 & - & 83 & - \\
\hline & & & $n$ & 23 Yuriage & 12 & 22.3 & 22.9 & 143 & 195 \\
\hline & & & Sept. & $28 \quad "$ & 48 & 23.9 & 29.0 & 164 & 348 \\
\hline & & & Oct. & 10 Matsugahama & 60 & 22.0 & 30.7 & 135 & 392 \\
\hline & \multirow{5}{*}{$\begin{array}{l}\text { st. } 6 \\
\left(38^{\circ} 04^{\prime} \mathrm{N}\right. \\
\left.141^{\circ} 14^{\prime} \mathrm{E}\right)\end{array}$} & 24 & Aug. & 21 Yuriage & 10 & 21.8 & 22.1 & 149 & 142 \\
\hline & & & $n$ & 27 Hashima & 16 & 21.3 & 23.3 & 135 & 172 \\
\hline & & & $"$ & 28 Yuriage & 17 & 23.7 & 27.1 & 212 & 290 \\
\hline & & & Oct. & $8 \prime \prime$ & 58 & 21.1 & 29.0 & 150 & 377 \\
\hline & & & $"$ & 26 Soma & 76 & 24.1 & 32.5 & 186 & 475 \\
\hline \multirow[t]{17}{*}{ Aug. 14} & \multirow{12}{*}{$\begin{array}{l}\text { st. } 7\left(38^{\circ} 06^{\prime} \mathrm{N}\right. \\
\left.141^{\circ} 05^{\prime} \mathrm{E}\right) \\
\text { st. } 8 \\
\left(38^{\circ} 04^{\prime} \mathrm{N}\right. \\
\left.141^{\circ} 09^{\prime} \mathrm{E}\right)\end{array}$} & 100 & Aug. & 22 Yuriage & 8 & 26.8 & 25.9 & - & 218 \\
\hline & & & Oct. & $16 "$ & 63 & 26.0 & 31.9 & - & 489 \\
\hline & & 84 & Aug. & 25 Hirakata & 11 & 25.3 & 26.0 & - & 233 \\
\hline & & & Sep. & 21 Kesen-numa & 38 & 30.4 & 33.2 & - & 513 \\
\hline & & & $"$ & 23 Tashiro isl. & 40 & 22.7 & 25.6 & - & 255 \\
\hline & & & $" 29$ & -30 Hirakata & $46-47$ & 23.6 & 28.5 & - & 382 \\
\hline & & & $n$ & 30 Yuriage & 47 & 21.9 & 28.1 & - & 327 \\
\hline & & & Oct. & 2 Fukanuma & 49 & 22.5 & 28.2 & - & 306 \\
\hline & & & $"$ & 26 Soma & 73 & 21.2 & 30.2 & - & 450 \\
\hline & & & $\begin{array}{l}\text { May } \\
(1972)\end{array}$ & 23 Hitachi & 283 & 27.1 & - & - & - \\
\hline & & & Jun. & 21 Onahama & 312 & 28.5 & 36.0 & - & 600 \\
\hline & & & July & 3 Matsukawaura & 324 & 22.2 & 32.0 & - & 489 \\
\hline & \multirow{5}{*}{$\begin{array}{l}\text { st. } 9 \\
\left(38^{\circ} 03^{\prime} \mathrm{N}\right. \\
\left.141^{\circ} 13^{\prime} \mathrm{E}\right)\end{array}$} & 121 & Aug. & 23 Hashima & 9 & 25.5 & 25.5 & $一$ & 231 \\
\hline & & & Sep. & 5 Kotakehama & 22 & 22.9 & 24.7 & - & 206 \\
\hline & & & $n$ & 21 Yuriage & 38 & 25.0 & 28.2 & - & 394 \\
\hline & & & Oct. & 12 Urajiri & 59 & 22.0 & 29.3 & - & 355 \\
\hline & & & $\begin{array}{l}\text { May } \\
(1972)\end{array}$ & 13 Hitachi & 273 & 26.0 & 35.8 & - & 800 \\
\hline Oct. 111972 & Orinohama, & 47 & Oct. & 15 Kyubunhama & 4 & 25.5 & 25.5 & 215 & 215 \\
\hline & st. 10 & & Dec. & $1 n$ & 51 & 29.7 & 30.0 & 348 & 500 \\
\hline
\end{tabular}




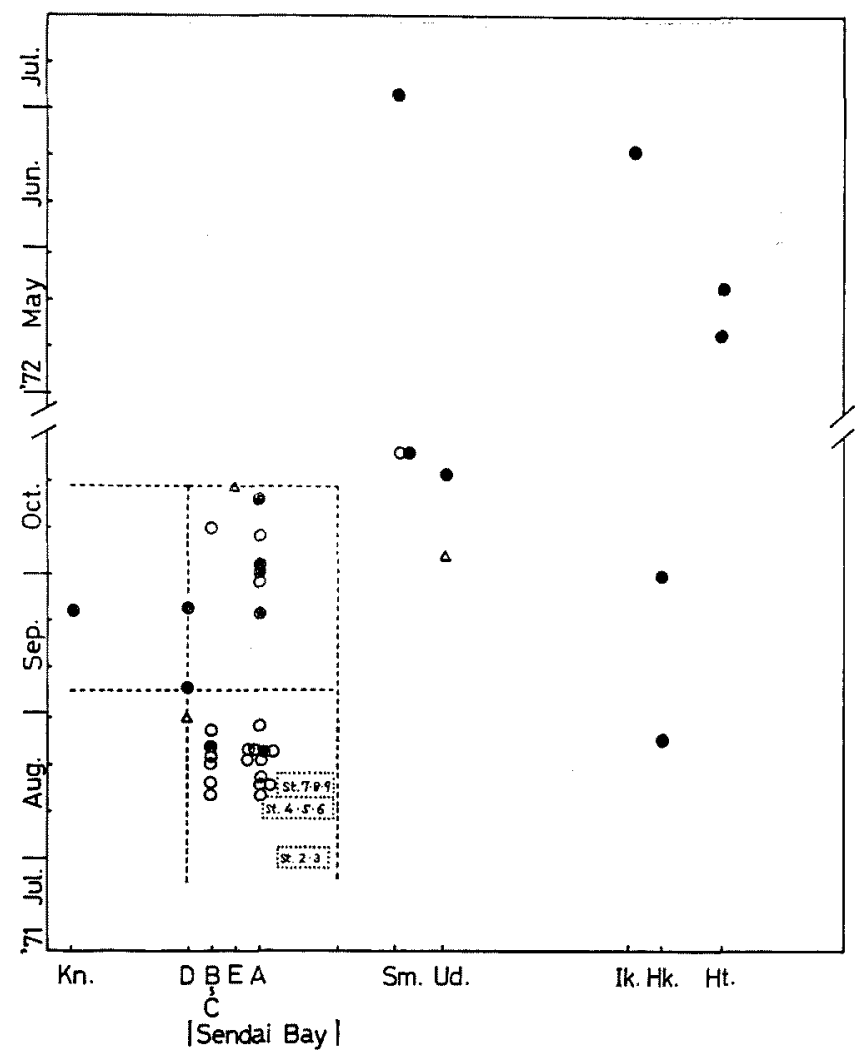

Fig. 4. Relationship between elapsed time after releasing and fishing area recaptured, in respect of marked young amberfish released in the Sendai Bay during the warm season from July to August in 1971.

$\triangle$ : group released at stations 2 and 3 .

O: group released at stations 4,5 and 6 .

- : group released at stations 7,8 and 9 .

$\mathrm{Kn}$ : Kesennuma

A, B, C, D, E: division of fishing ground in the Bay.

Sm: Soma Ud: Ukedo Ik: Iwaki Hk: Hirakata Ht: Hitachi

showed scarcely any feeding behavior, and finally died out all at about $5-5.5^{\circ} \mathrm{C}$.

\section{Discussion}

At the period, when the Kuroshio water mass draws toward the coast of the Sendai Bay, in an ordinary year, the amberfish migrate to the neighbouring area of the Bay. According to records of catch by the representative set-nets along the coast of Fukushima and Miyagi Prefectures, during the period from 1967 to 1971, as shown in Table 5, both large and medium sized amberfish show clearly a migrating tendency, going up north from a direction of Joban in good order with lapse of time, from late in April to May. In case 


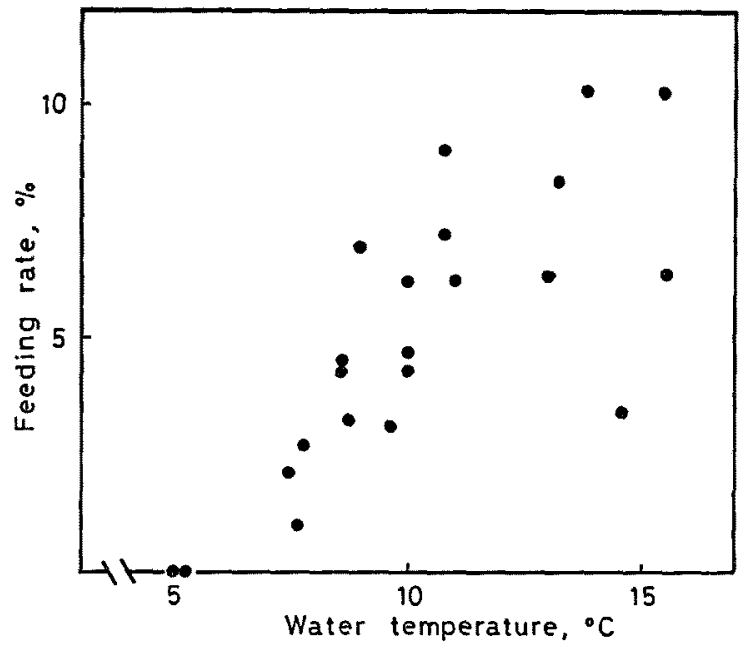

Fig. 5. Relationships between the water temperatures and the 30 minutes feeding rate of the young amberfish fed with the anchovy at every 24 hours interval.

of small sized fish, in 0-age of year, however, such a time lag is scarcely seen between south and north sea areas. The phenomena gives an account of that fish in 0 -age of year show a typical life form ecologically different from the larger sized; during the stage below $10-15 \mathrm{~cm}$ in fork length they spread their living zone to the northward keeping mainly with the movement of drifting sea-weeds carried by Kuroshio current from southern coast

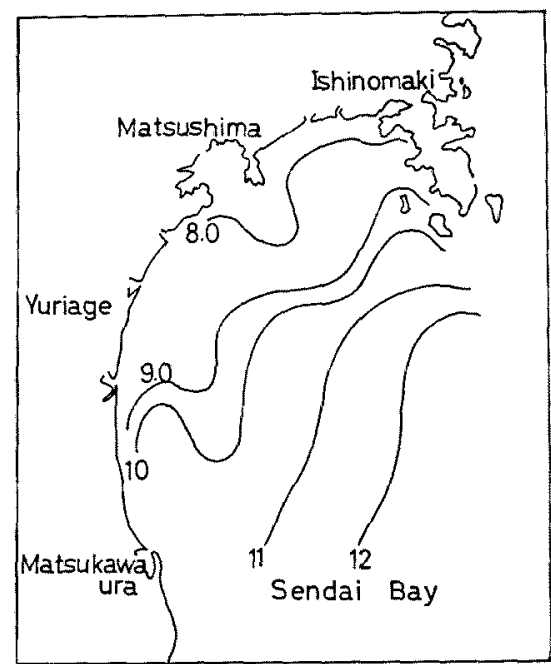

Fig. 6. Distribution of surface water temperature in the Sendai Bay, in Feburuary 1972 (after Kudo, 1972). of Japan. And especially, the occurrence of the fish at northern coasts of headland of Inubo, may have been influenced by the distribution of warm water mass along the coast of Tohoku Region, and by the location where the jouvenile fish attain exactly a developmental stage to change its passive drifting life to active or unrestricted life in the coast.*

Gathering from the tagging experiments of the young amberfish in 0-age of year, which migrated into the coast of the Bay apart from the drifting-sea-weeds, some schools go up northern area and the others advance southward along

* A. Okata and M. HatanaKa: Speech in Ann. Meet. of Jap. Soc. of Sci. Fish., Tokyo, April, 1973. 
Table 5. Dates, when the amberfish caught for the first time in each year, during the period from 1967 to 1971 , separately for the several set-nets set along the coast of Fukushima and Miyagi prefectures

Note; L, large $\mathbf{M}$, medium $\mathbf{S}$, small

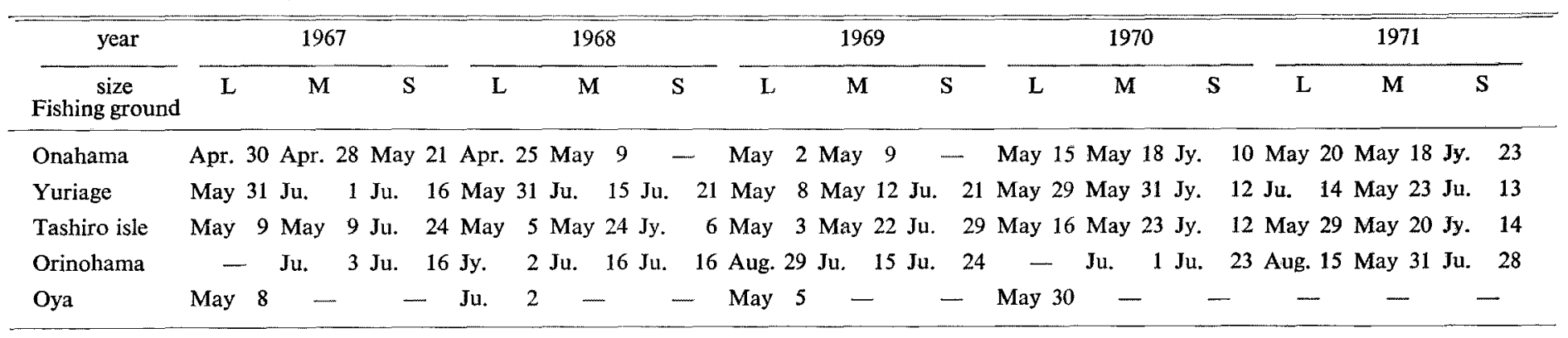


the coast of Joban. On the other hand, some part of schools migrated in the coast of Joban, go up northward and get to the Sendai Bay. Accordingly, it may well be that interchange of fish schools between adjacent sea areas will considerably occur in this manner.

Seeing the movement of schools in broad perspective, the young amberfish, migrated in the Bay, are sojourning in the same area or adjacent sea areas during warm season, and move their living region to southern area keep pace with falling trend in water temperature, during the period from late in September to the beginning of October.

The surface water temperatures in the Sendai Bay on Feburuary, showing the lowest record, as shown in Figure 6, generally becomes below $11^{\circ} \mathrm{C}$ in an average, and shows under $9^{\circ} \mathrm{C}$ in the area of the fishing ground of set-net along the coast ${ }^{10)}$. From a comparison of the result of the rearing experiment on condition of lower temperature with the distributional state of the water temperature of the Bay in winter is improper for the normal feeding life of young amberfish. Accordingly, it is fairly conceivable that in winter the centroid of the amberfish population advance southward in search of suitable conditions for life. On the other hand, during the winter months, some of the young amberfish are caught in the area along the coast from southern part of Ibaraki Prefecture to the Boso peninsula. In addition to this fact, judging from the states of growth rate of the fish recaptured in the next spring at the coast of Tohoku Region, there is a fair chance for that some of young amberfish will stay over the clodest season at least in the neighbouring areas of the Boso peninsula. And, about in May of the following year, turning to a different direction, they begin their migration toward Tohoku Region the north sea area from Inubo.

\section{Acknowledgement}

Grateful acknowledgement is made to Professor Emeritus M. Hatanaka, Tohoku University, for suggesting this problem and for stimulating interest in it, and for constant guidance in the course of the work. The author wishes to express heartful thanks to Dr. R. SATo and Dr. S. Nishizawa, Tohoku University, for many valuable suggestions. Thanks are also due to various members of the laboratory staff of Department of Fisheries, Faculty of Agriculture, Tohoku University, and the author has also benefited from the advices and criticisms of members of a research group for JIBP-PM in the Sendai Bay. Records of daily amount of catch by the set-nets were kindly offered by Messrs S. OKAWA, I. KameYAMA, H, KanNo and the Fisheries Associations of Tashiro island, Oya, Onahama Marukyo and Ose. The author is deeply indebted to Mr. K. Okizaki and a crew of the Takusui, Fisheries Experimental Station of Fukushima Prefecture, for their considerable assistance with the tagging experiment at far coast of Joban.

In preparing this presentation, the author is grateful to Mr. WATANABE, Chief Scient- 
ist of Fisheries Experimental Station of Ibaraki Prefecture, for helpful suggestions and observation and a critical reading of the manuscript.

This work was supported financially in part by a Grant in Aid for Fundamental Scientific Research of the Ministry of Education.

\section{References}

1) A. OKaTA: This Bull., 41, 1247-1262 (1975).

2) A. OKATA: ibid., 42, 29-44 (1976).

3) A. Okata, K. Ishikawa, T. Murata, and M. Hatanaka: Interim Report of the Studies on the Sendai Bay for JIBP/PM, No. 2, 141-158 (1969).

4) A. OKata and M. Hatanaka: ibid., No. 3, 77-84 (1970).

5) A. OKata and Y. ChIDA: ibid., No. 4, 67-76 (1971).

6) A. Okata, H. Abe, K. Uchino, H. Hanabuch, Y. Chida, and M. Hatanaka: ibid., No. 5, 79-106 (1972).

7) F. Mrtani: Memoirs of the Faculty of Agriculture of Kinki Univ. 1 (1960).

8) ANON: Mojako saiho no buri shigen ni oyobosu eikyo ni kansuru kenkyu hokokusho, (Continued Report), Tokai Reg. Fish. Res. Lab. and others, 99 p. (1970).

9) S. Tanaka: This Bull., 38, 29-32 (1972).

10) H. KUdo: Interim Report of the Studies on the Sendai Bay for JIBP/PM, No. 5, 11-23 (1972). 